\title{
The Influence of the Global Perfumery Market on the Principles of the Formation of a Tourist Flow
}

\author{
HALYNA ZAIACHKOVSKA ${ }^{1}$, VIKTORIIA TSERKLEVYCH ${ }^{2}$, SVITLANA VOVK ${ }^{3}$ \\ ${ }^{1}$ Marketing and Management Department, KHMELNYTSKYI COOPERATIVE TRADE AND ECONOMIC INSTITUTE, \\ KHMELNYTSKYI, UKRAINE. \\ ${ }^{2}$ Hotel and Restaurant and Tourism Business Department, KHMELNYTSKYI COOPERATIVE TRADE AND \\ ECONOMIC INSTITUTE, KHMELNYTSKYI, UKRAINE. E-mail: w.zerklevitch@gmail.com \\ ${ }^{3}$ Department of International Tourism and Hospitality Business, WEST UKRAINIAN NATIONAL UNIVERSITY, \\ TERNOPIL, UKRAINE.
}

\begin{abstract}
Based on the research results, it was concluded that the formation of world tourist flows essentially depends on the level of development of the perfume industry within the country and the individualization of the population's income in this direction.

This material also describes the history of the production of perfumes, special attention is paid to the leading centers for the production of raw materials, semi-finished products and finished products. To clarify the results, an analysis of the perfumery industry market was carried out for specific geographic regions, and the balance of forces in the global perfumery and cosmetics industry was determined. A typology of various countries of the world has been created according to the nature of perfumery and cosmetic products.

The article's authors also identified the key players in the global perfumery market, identified individual market segments and trends in their development. It became possible to explain the reasons for the development of world tourism in the growth of the perfume market. The work also proposes a definition of perfume tourism, which at its core takes into account the commodity-money relations that arise during the journey. The experimental part of the study made it possible to determine consumers' attitudes to perfume tourism and its peculiarities.
\end{abstract}

Keywords: perfumery market, perfume tourism, classification of perfume tourism, tourist demand

JEL Classification: M31, L66, Z31, Z32

Received: 5 May 2021

Accepted: 16 May 2021 


\section{Introduction.}

Formulation of the problem. Pretty high dynamics and stability levels characterize features of tourism development in the late 20th - early 21st century. At the same time, the primary consumer of tourist services has become precisely the middle class, which is sufficiently interested in travel and everything connected with it.

The material well-being of these people determines their needs and preferences. Travel ceases to be a luxury as it becomes a must for everyone to satisfy their interests and enhance their unique experience. E. Engel proved in the 19th century that as the average income of the population rises, it begins to pay less and less attention to essential goods, concentrating on luxury goods [1].

Such changes in the consumption structure contribute to an increase in demand for themed tours, namely perfume tourism.

Perfume is a mixture of aromatic oils or aromatic compounds, fixatives, and solvents used to give the human body a pleasant smell [2, p.251]. The perfumery market offers various groups of non-food products used to express a person's individuality, emphasizing his social status and additional confidence.

It is worth noting that the US and European markets are the leaders and trendsetters in the perfume market. Their share is the largest. In 2018, France's market share was $25.9 \%$, while Germany's was $16.3 \%$. A significant number of factories of various perfume brands are located in France, and state revenues from the sale of products of this category in 2017 amounted to 4.8 billion US dollars. It is about a quarter of all world exports of perfumery [3]. Moreover, at the tourism and perfumery exhibition organized by the European Tourism and Trade Council in 2017, a new tourism program was launched, which is based on visits to perfume centers and regions of France [4].

The emergence of perfume tourism is driven by an increase in global demand for exotic and luxurious fragrances, an increase in household income, and an increased emphasis on quality and personalization by perfume manufacturers. The possibility of creating your products, the trend towards using sustainable perfumes based on natural raw materials forms the need for this research.

\section{Analysis of recent research and publications.}

Perfume tourism is a new type of tourism, so a small number of works are devoted to its research. O. Popova attributes perfume tourism to new types of tourism by interests, the emergence of which is caused by changing the needs of individuals, the desire to get previously unknown impressions, new feelings and the desire for self-expression [5]. V. Patsyuk considers perfume tourism as industrial, which means "active tourism, concentrated in industrial areas, which aims to study industrial landscapes, acquaintance with examples of industrial architecture, visits to existing industrial enterprises to meet cognitive, professional, business goals" [6]. S.S. Polyanina, L.V. Dokashenko considers perfume tourism as a type of industrial tourism - excursions to the enterprise [7]. I. Boulhosa, B. Casais attribute the purchase of perfumes of well-known brands abroad to shopping tourism, as they are included in the list of goods in greatest demand [8]. M.P. Gag and FF Sandor treats perfume tourism as "a type of tourism whose main purpose is to visit regions associated with the perfume industry" [9].

Despite the existence of various approaches to determining the place of perfume tourism in the classification of types of tourism, there are no fundamental developments to establish its essence.

The material for the study was Euromonitor International, Mordor Intelligence, Grand View Research Inc., Future Market Insights, Statista, Cosmetics Business, International Tourism Highlights, Eurostat; materials are posted on the websites of the International Institute of Perfumery, Cosmetics and Food Flavors ISIPCA, perfume factories, perfume museums, scientific publications and materials collected during marketing research. 


\section{Research Methods.}

The methodology and research methodology are based on a dialectical approach, according to which perfume tourism is considered in the relationship and interdependence with international tourism. In the course of the research, general and special methods were used: abstract-logical when reviewing the scientific literature on this topic; analysis, synthesis, scientific generalizations for scientific substantiation of the concept of "perfume tourism"; methods of scientific abstraction, induction and deduction, comparative analysis - in identifying trends in the functioning of the perfume market; economic and statistical analysis, comparison and synthesis - to quantify the functioning of the market; questionnaire method - to determine the attitude of consumers to perfume tourism. In studying the phenomenon of perfume tourism, we were based on the theory of the static class of T. Veblen. Tabular and graphical methods were used to systematize and group the information.

\section{Research Results.}

The volume of the global perfume market in 2019 was estimated at 43.9 billion dollars. USD, which is 4.3 billion dollars. The United States is more prominent than in 2016 [10]. According to forecasts, its volume by 2025 will be 52.4 billion dollars. USA [11], and the overall average annual growth rate is projected at 5.5\% during 2020-2025 [12]. The rapid growth reflects the tendency of young people to pay more attention to personal care in combination with an increase in living standards in developed countries; individualization of consumer needs. The growth of their costs for luxury perfumes and niche products that have a concentration of fragrances from $15 \%$ to $40 \%$. Production of perfumes based on natural ingredients to prevent allergic reactions of the body. However, the availability of counterfeit products and harmful chemical components are among the factors that may hinder the growth of the global perfume market during the forecast period.

Key players in the market are Coty Inc., L'Oreal, LVMH and Estée Lauder. At the same time, other well-known perfume manufacturers include Shiseido Co. Ltd, Revlon Inc., Chanel SA, Hermès International SA and Avon Products Inc.

The main criteria for segmenting the global perfume market in terms of demand are:

a) type of goods: perfumes, perfumed water, eau de toilette, cologne;

b) group of consumers: women, men, unisex [13].

In 2018 , the countries with the largest perfume market were the United States -8.4 billion USA dollars, Brazil -6.9 billion USA dollars, Germany -2.7 billion USA dollars, France -2.6 billion USA dollars and the UK -2.5 billion USA dollars. Global sales of luxury perfumes compared to the mass market in 2018 amounted to 30.5 billion USA dollars, respectively, USA dollars, which is $5.1 \%$ more than in 2017 and 20.5 billion USA dollars, which is 1.3\% less than in 2017 (Table 1). It is due to the increase in demand for niche supply while reducing the value of perfumes in the mass market.

Table 1. Global sales of luxury perfumes compared to the mass market by market segments

\begin{tabular}{|l|c|c|c|c|}
\hline \multicolumn{1}{|c|}{ Indexes } & $\begin{array}{c}\text { Luxury perfumes, } \\
\text { billion dollars } \\
\text { USA }\end{array}$ & $\begin{array}{c}\text { Deviation } \\
\mathbf{2 0 1 8 / 2 0 1 7}, \\
\mathbf{\%}\end{array}$ & $\begin{array}{c}\text { Mass market } \\
\text { perfumes, billion } \\
\text { dollars USA }\end{array}$ & $\begin{array}{c}\text { Deviation } \\
\mathbf{2 0 1 8 / 2 0 1 7}, \\
\mathbf{\%}\end{array}$ \\
\hline Global sales & 30,5 & $+5,1$ & 20,5 & $-1,3$ \\
\hline Women's perfume & 16,8 & $+5,0$ & 10,9 & $-1,0$ \\
\hline Men's perfumes & 8,4 & $+4,6$ & 8,2 & $-1,6$ \\
\hline Unisex & 2,4 & $+7,5$ & 0,3 & $-0,9$ \\
\hline
\end{tabular}

Source: based on Euromonitor International [14]

Perfumes have become an essential product that builds a person's confidence, indicates his status and is a "means of maintaining reputation" [15, p. 142]. Perfumes are not a necessity, incredibly niche, so their purchase is motivated by the desire to achieve a specific position both in the eyes of the reference group and in their own [16, p. 42]. Scientists note that the purchase of goods that go 
beyond what is necessary; the consumer has limited access to it due to its high price or rarity, corresponds to the status of consumption [17, p. 125]. In addition, the emergence of a new trend in the relationship between fashionable clothing and fragrance has led to the fact that almost all manufacturers of trendy branded clothing seek to create an aromatic quintessence of their own style, regardless of the season or collection. Their advertising campaigns in bringing new perfumes to market increasingly turn to the aspect of elitism [18, p. 320]. Since most perfume and fashion brands are concentrated in Europe, the desire of consumers around the world to buy perfumes that have just appeared on the market leads to travel to other countries.

The level of development of the perfume industry, which meets the needs of consumers by creating competitive perfume products, the promotion of perfume culture affects the development of tourism in the country or region. The center of the world's perfume industry is in France. It is home to the most significant market players; it is also developed in Italy, Switzerland, Great Britain, Austria and Poland.

In France since the early 1990s of the twentieth century, tourism has become one of the most powerful sectors of the economy. In terms of international tourist arrivals in 2018, the country ranked 1st in the world due to cultural and exceptional natural resources - 89 million people [19]. About 300 perfume and cosmetics companies in the French market and perfume production are concentrated in and around Paris.

Perfume tourism is a type of thematic tourism that involves people traveling to visit cities and regions associated with the perfume industry.

A review of the literature confirms that there is no generally accepted definition of perfume tourism; it is associated with both the perfume industry and tourism, especially inbound. As the centers of the perfume industry are concentrated in Europe and the United States, perfume tourism is international. The concept of "international tourism" is the basis for the definition of "perfume tourism". UNWTO uses the meaning of the United Nations Statistical Commission, which means that international tourism is "the activity of persons traveling and staying outside their usual habitat and for a period not exceeding one calendar year, for leisure, business and other purposes» [21]. Using the interpretation of the essence of the concept of "international tourism" as "activity" allows us to consider the essence of perfume tourism as "activity" of individuals or enterprises.

On the one point of view, the argument in favor of this is considering a person's activity as interaction with tourism service providers. Human needs are met in the knowledge of the world of perfumes, their production, their components, and the acquisition of branded fragrances, the process of production and the provision of tourist services. Combining these two points of view makes it possible to characterize perfume tourism as a socio-economic activity.

Defining the meaning of the concept of "perfume tourism" requires the establishment of a mechanism for implementing its essence. Based on the fact that the development of tourism is associated with commodity-money relations, we believe that the meaning of the concept lies in the processes of production of tourist services, international exchange and consumption.

The construction of the concept of "perfume tourism" involves determining the result, which leads to the implementation of this phenomenon. In our opinion, the result of a person's journey has a threefold character. First, there is the satisfaction of social needs on vacation, and secondly economic, for example, the purchase in other countries of cheaper, higher quality or unique perfumes; third - aesthetic (emotionally expressive pleasure). Based on the above, we propose the following definition:

Perfume tourism is a sphere of socio-economic activity, which includes the provision of tourist services in the centers of the perfume industry and regions of raw materials and its exchange in the market of tourist services, which provides temporary departure of the consumer -economic and aesthetic needs. 
The study of places visited by people interested in the development of the perfume industry, allowed to identify the following types of perfume tourism: perfume educational tourism; perfume tours; perfume museum tourism; perfume ecotourism and events (Fig. 1).

Figure 1. Types of perfume tourism

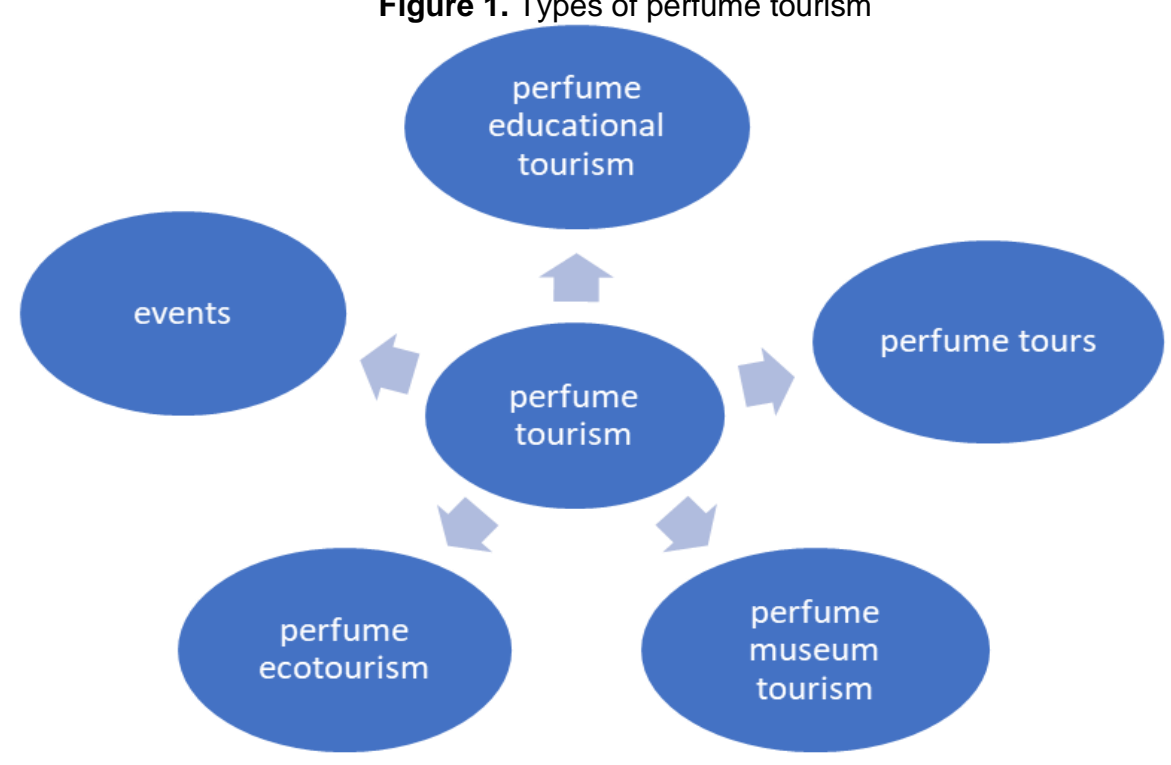

Source: developed by the authors

Perfume educational tourism - perfume education can be obtained in the following institutions [22]:

- International Institute of Perfumery, Cosmetics and Food Flavors ISIPCA, founded by J.-J. Guerlain (France) - the only open institute in the world that issues diplomas of international standard for additional education in "perfumer" (accepting 20 students per year);

- School of the Swiss perfume concern Givaudan (Paris, France) - only five employees of the concern are accepted annually; in Givaudan, new fragrances are regularly sought after by Calvin Klein, Bijan, Tom Ford, Marc Jacobs, Ralph Lauren, Hugo Boss and Paco Rabanne;

- Grasse Institute of Perfumery (Grasse, France) - accept 12 students annually for a 9-month course, offer short summer courses for beginners and advanced perfumers;

- Cinquieme Sens School (Paris, France) - offers master classes on making your perfumes and short courses for everyone;

- perfume houses Gallimard, Fragonardi and Molinard (Grass, France) - offer master classes on creating your perfumes, aimed primarily at tourists.

Perfume tours - excursions, the program of which includes visits to famous perfume and fashion houses, acquaintance with niche and particular brands of perfumery, participation in the creation of new aromas, consultations of perfumers, theoretical and practical employment in aroma studio (acquaintance with bases of creation of perfume compositions), typologies of flavors and aromatic substances), acquaintance with the latest trends in the market. The world centers of perfume tourism are the French castle of Chamrol, during the XVI-XX centuries; experienced perfumers worked, its attraction is a perfume body, which consists of two hundred and seventy essential oils; Grass, where the Galimard, Fragonard and Molinard perfume factories are located, where you can buy exquisite perfumes or create your own, Cologne, which has the oldest perfume factory in the world, and others.

To preserve the heritage of perfumers in many countries worldwide are opening perfume museums based on perfume factories or traditional. Perfume museum tourism involves visiting museums related to the history and technology of perfume production. The most famous of them are [23], [24]: 
- Fragonard Museum of Perfumes (Paris, France) - introduces the history of perfumes, the technology of their production; fragrances from all over the world, exposition of decor for houses and various design objects, products from semiprecious stones are presented, the opportunity to buy perfumes of factory "Fragonar" at the price of the producer and other production is given [25];

- Museum of Perfumery and Library of Fragrances Osmoteka (Versailles, France) - the central perfume storage of the planet, which is located on the territory of the International Institute of Perfumery, Cosmetics and Food Flavors ISIPCA; its mission is to preserve the world's perfume heritage (a collection of more than 3,000 bottles, 400 of which are no longer produced), to study ancient perfumes and to restore fragrances whose formulas have been lost;

- Regia Perfume Museum (Barcelona, Spain) - perfume containers from the times of Ancient Greece and Ancient Egypt, vintage bottles of famous perfume houses, antique packaging and perfume posters;

- International Museum of Perfumery Musee de La Parfumerie (Grasse, France) - presents the history of civilization through the prism of perfumery, "know-how" related to the use of fragrances, raw materials, production technology and design; a greenhouse with plants from which perfumes and interactive devices are made, which emit a smell when a button is pressed [26];

- FarinaHouse Cologne Museum (Cologne, Germany) - dedicated to "Eaude Cologne" (Eaude Cologne), which the Italian perfumer J.M. Farina invented in 1709; presents different types of equipment used for distillation of the original cologne, bottles from the VIII century. to this day, ancient documents; shows the evolution of cologne over time, including forgeries [27];

- Palazzo Mocenigo Museum of Perfume and Costume (Venice, Italy) - a unique collection of exhibits, some of which belong to the period of the Roman Empire; thematic halls give an idea of the ancient components of perfume, including frankincense, resin, vanilla, etc .;

- Perfumeria Gal Museum (Madrid, Spain) - a museum of perfumery of the famous factory "Perfumeria Gal", which collects the artistic, cultural and industrial heritage of the factory from 1898 to the present; presents the history of favorite Spanish perfume brands, posters for perfume advertising, created by the best illustrators of the twentieth century (Julio Romero de Torres, Rafael de Penagos, Salvador Bartolozzi, etc.), the evolution of industrial design in perfumery is seen in bottles, labels and boxes 28];

- Museo del Profumo perfume museum (Milan, Italy) - dedicated to the history, design and art of making glass bottles created for vintage perfumes in the XIX-XX centuries. such well-known designers and artists as Rene Lalique ("Scarabée" perfume bottle), Carlo Scarpa, Julien Viardo, Fulvio Biancone, Salvador Dali ("Le Roy Soleil” perfume bottle) and others. [29];

- The Cairo Museum of Perfume (Cairo, Egypt) - a large collection of fragrances that allow you to trace the millennial history of perfume production in the country and the ancient technologies of obtaining fragrances; favorite fragrances of Cleopatra and Pharaoh Ramses, handmade bottles inlaid with precious stones, made by master jewelers [30];

- Museum of Perfumes in Andorra - has a permanent exhibition, which focuses on the history and evolution of perfumes in the XX century, when they began to grow in popularity; 39,000 units of perfume were presented; in one of the rooms, visitors can experiment with creating different flavors with the help of equipment.

Perfume ecotourism (green tourism) - visiting areas where flowers and other plants are grown, from which essences for the perfume industry are made, such as lavender fields and jasmine in Grasse. Flowers are harvested as soon as they bloom because the concentration of oils in them is maximum. From here, they supply raw materials to Europe. A total of about 300 names of various aromatic substances and essential oils are used to make perfumes.

Events - organization of meetings with famous "noses", presentations of new perfumes of wellknown brands, perfume exhibitions, conferences of representatives of the perfume industry, etc. 
In order to determine the attitude of consumers to perfume tourism, a marketing survey was conducted, which involved 508 respondents from the cities of Khmelnytsky and Ternopil, including 439 people - women and 69 - men over 18 years of age. Gender-based segmentation of respondents is due to their different attitudes towards perfumery.

The study found that $98.4 \%$ of women and $1.6 \%$ of men use perfumes, $61.9 \%$ - prefer luxury perfumes, $38.9 \%$ - mass-market, $11.9 \%$ - niche perfumes (Fig. 2). Thus, women are the primary consumers of perfumes in Ukraine, both in the premium and in the mass market. The preference for luxury perfumes is due to the growing purchasing power of consumers who choose expensive brands when income allows.

Interestingly, $65.1 \%$ of respondents buy perfumes when traveling abroad; the main reasons were the lack of counterfeits $-36.8 \%, 16.8 \%$ received a lower price, a more comprehensive range and the opportunity to buy luxury perfumes. $69.8 \%$ of respondents named the primary motive for buying perfumes the desire to have a pleasant smell, $16.7 \%$ - the desire to change the mood, $6.3 \%$ - the desire to impress and only $1.6 \%$ - to emphasize social status (Fig. 3).

Figure 2. Classes of perfumery, which Ukrainian consumers prefer

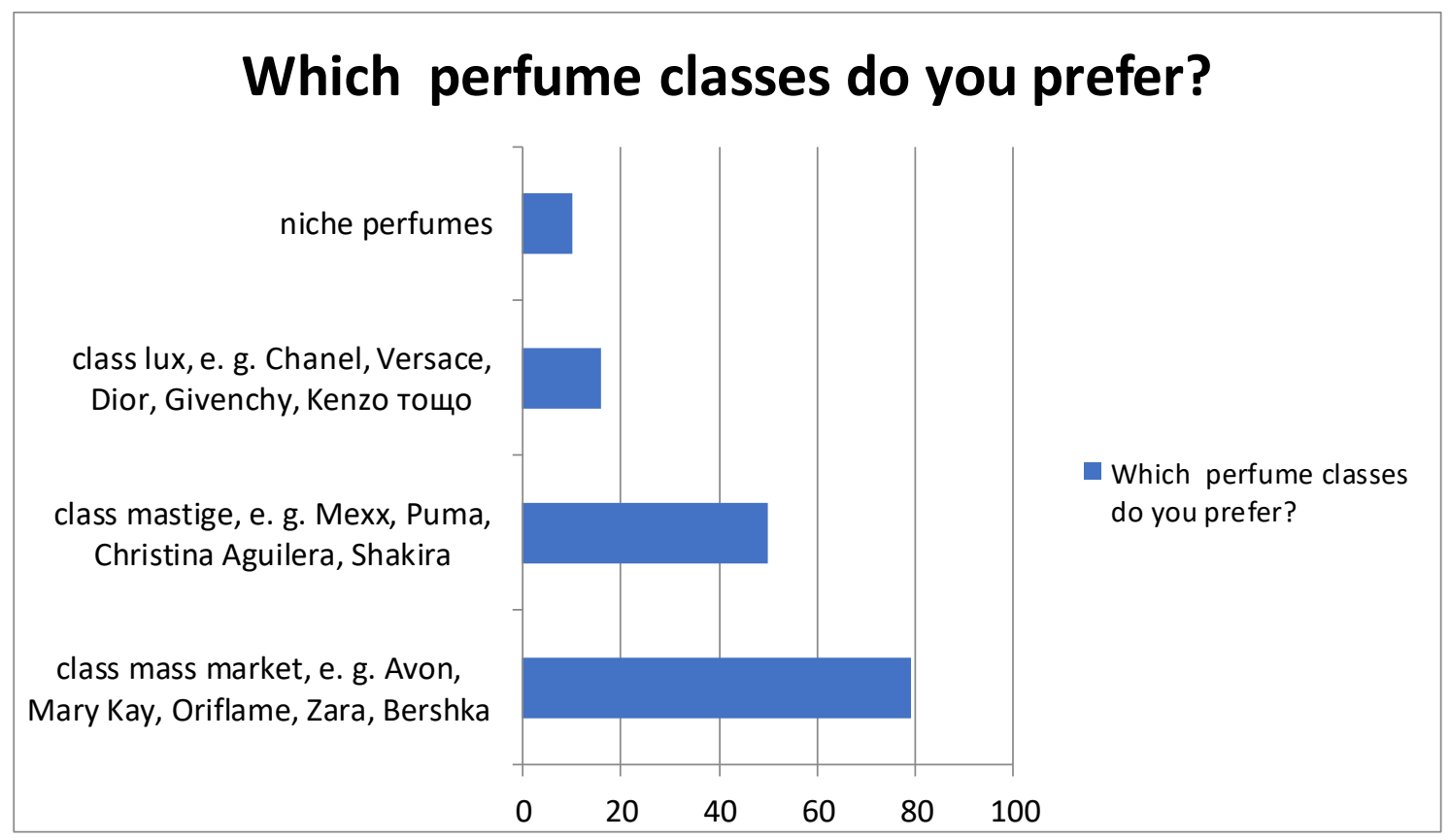

Source: developed by the authors

If possible, $66.1 \%$ of respondents would go on a perfume tour. The main reasons include attending a master class on creating your perfume $-27 \%, 21.3 \%$ - interest in the history of perfumes and technology of their production, $12.4 \%$ received the opportunity to purchase perfumes of wellknown brands and visit places where flowers and other plants are grown, the oils of which are used in the creation of perfumes, $11.2 \%$ of respondents would like to visit museums of perfumes and events (Fig. 4).

Thus, the results of the study indicate that the main reasons for perfume tourism, domestic respondents indicated attending workshops on creating their own perfume and interest in the history of perfumes and technology of their production. The obtained data confirm the fact that perfume tourism has significant development potential. 
Figure 3. Motives for the use of perfumes

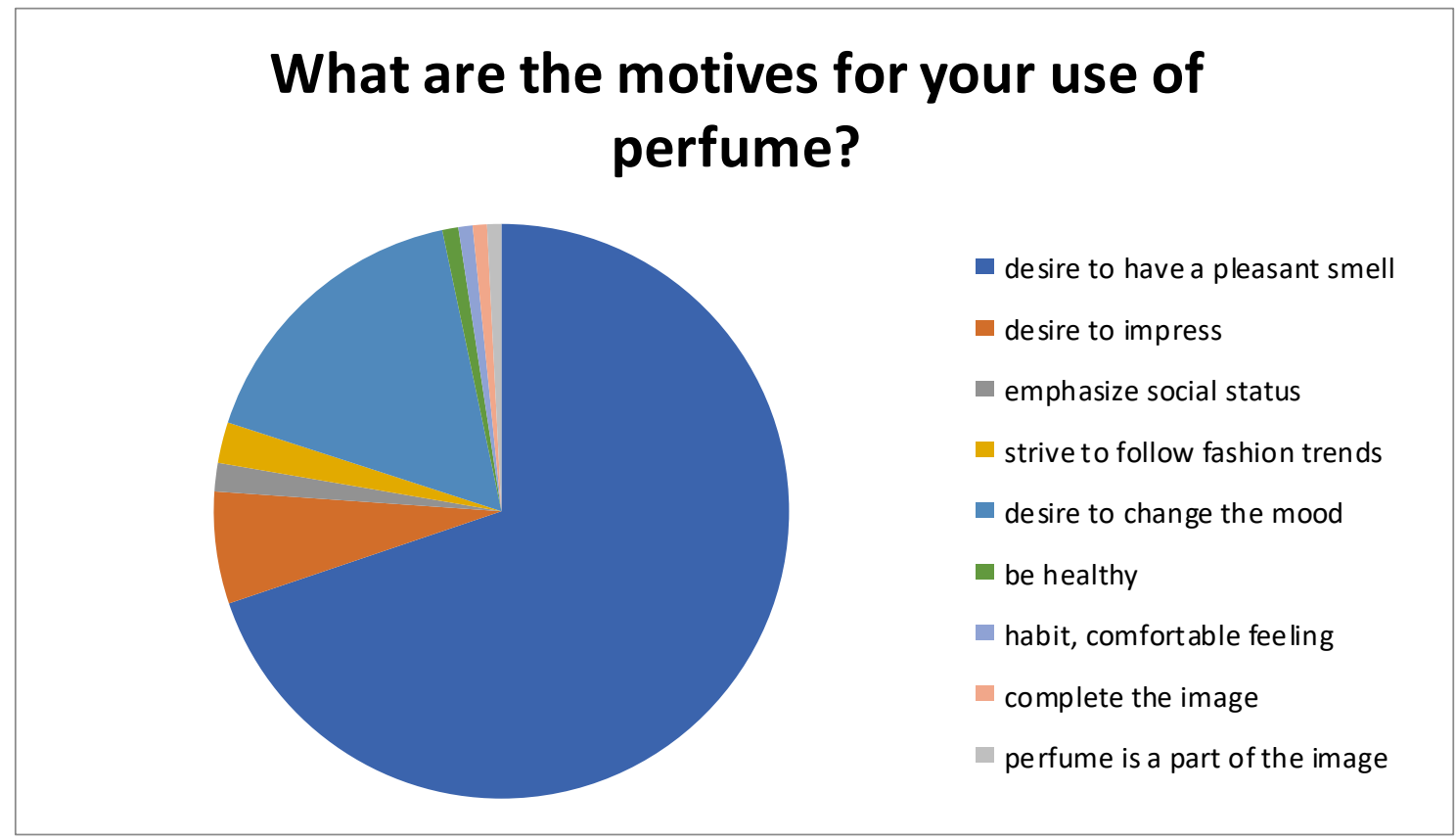

Source: developed by the authors

Figure 4. Reasons for respondents' interest in the perfume tour

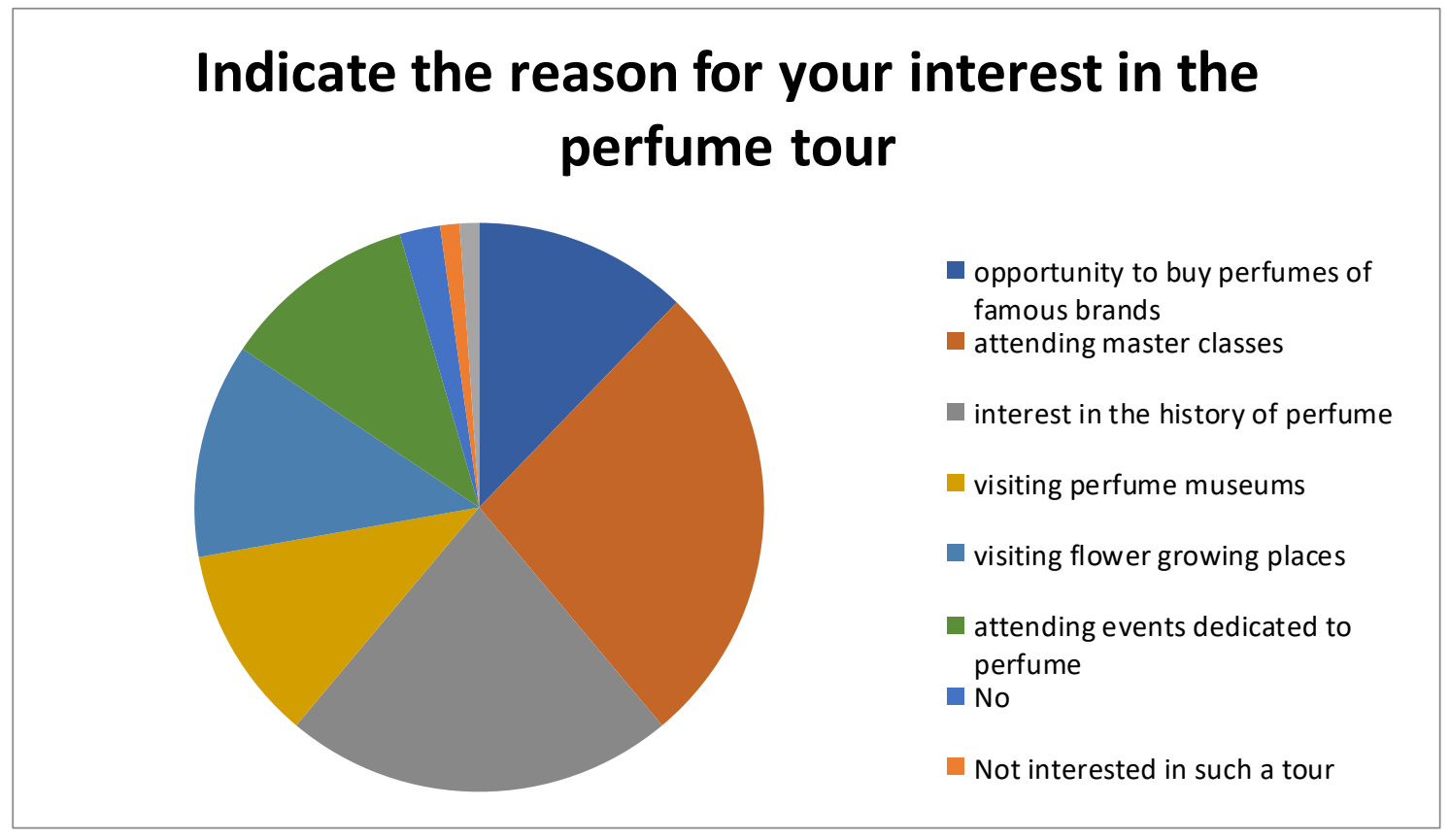

Source: developed by the authors

\section{Conclusions and Prospects of Further Research.}

Based on the above, we can conclude that perfumes have become an essential part of everyday life. The popularization of the regions of the perfume industry influences the formation of world tourist flows, promotes the growth of international tourist arrivals and revenues from international tourism in the centers of perfume tourism.

In further research, it is necessary to focus on forming theoretical foundations of perfume tourism, analysis of marketing trends that shape the perfume market. 


\section{References}

1. Yakovenko R. Fundamental Economic Laws of Consumption. https://rk.kr.ua/fundamentalniekonomichni-zakoni-spozhivannja-chastina-1

2. Arun Nanda, Sanju Nanda, Tuan Anh Nguyen, Susai Rajendran, Yassine Slimani. (2020). Nanocosmetics: Fundamentals, Applications and Toxicity, Elsevier, 504 p. https://books.google.com.ua/books?id=vOjeDwAAQBAJ\&pg=PA251\&lpg=PA251\&dq=is+a+mixtur e+of+fragrant+essential+oils+or+aroma+compounds,+fixatives+and+solvents, +used+to+give+the+ human+body, +animals, +food,+objects, +and+living-

spaces+an+agreeable+scent\&source=bl\&ots=bJIH5j32j9\&sig=ACfU3U3me8mTLtvoxx6xOmjtYim5p sSu-

Q\&hl=ru\&sa=X\&ved=2ahUKEwjf5oGPmbrqAhXQwosKHVJuArQQ6AEwAXoECAkQAQ\#v=onepage\& q=is\%20a\%20mixture\%20of\%20fragrant\%20essential\%20oils\%20or\%20aroma\%20compounds\%2 C\%20fixatives\%20and\%20solvents\%2C\%20used\%20to\%20give\%20the\%20human\%20body\%2C\%2 Oanimals\%2C\%20food\%2C\%20objects\%2C\%20and\%20livingspaces\%20an\%20agreeable\%20scent\&f=false

3. Perfume Market Size, Share \& Trends Analysis Report By Product (Mass, Premium), By End User (Men, Women), By Distribution Channel (Offline, Online), By Region, And Segment Forecasts, 2019 - 2025. https://www.grandviewresearch.com/industry-analysis/perfume-market

4. Dali Haute Parfumerie Creator of World Favorite Perfume Recognized as France Perfume and Tourism Center. https://www.travpr.com/pr-60554-dali-haute-parfumerie.html

5. Popova, E. V., Shevchenko A. A. Segmentation of Tourism Is a Reflection of the Current State of the Tourist Market. http://ej.kubagro.ru/2013/05/pdf/61.pdf

6. Patsyuk, V.S. (2008). Industrial tourism and perspective development in Ukraine. Geography, 15, p. 83.

7. Polyanina, S.S., Dokashenko, L.V. The Essence of Industrial Tourism and Its Types. http://elib.osu.ru/bitstream/123456789/768/1/1773-1776.pdf

8. Boulhosa, I., Casais, B. (2019). Motivations for Tourism Shopping in Department Stores: An Exploratory Research about Tourists' Profiles Visiting El Corte Inglés Gaia. European Journal of Tourism, Hospitality and Recreation, 9(1), pp. 18-26.

9. Klyap, M.P., Shandor, F.F. (2013). Modern varieties of tourism, Znannya, $334 \mathrm{p}$.

10.Perfumes Market: Western Europe to Account for Maximum Revenue Share: Global Industry Analysis and Opportunity Assessment, 2016-2026

https://www.futuremarketinsights.com/reports/global-fragrances-market

11.The size of the global perfumery market from 2013 to 2025 (in billions of US dollars). https://www.statista.com/statistics/259221/global-fragrance-market-size/

12.Fragrance and Perfume Market - Growth, Trends and Forecast (2020-2025).

https://www.mordorintelligence.com/industry-reports/fragrance-and-perfume-market

13.Global Fragrances and Perfumes Market (2020-2025).

https://samples.mordorintelligence.com/62651/Sample\%20-

\%20Global\%20Fragrances\%20and\%20Perfumes\%20Market\%20(2020\%20-\%202025)\%20-

$\% 20$ Mordor\%20Intelligence.pdf

14.Cosmetics Business reveals the 5 largest fragrances in a new report. https://www.cosmeticsbusiness.com/news/article_page/Cosmetics_Business_reveals_the_5_bigg est_fragrance_trends_in_new_report/155392

15.Veblen T. (1984). Leisure class theory. Moscow: Progress, 367 p.

16.Eastman, J. K., Goldsmith, R. E., Flynn, L. R. (1999). Status consumption in consumer behavior: scale development and validation. Journal of Marketing Theory and Practice, 7(3), pp. 41-52. 
17.Schavel S.A. (2010). Consumption and stability of society. Minsk: Belarusian Science, 316 p.

18.Faiers, J. (2017). Stinking to high heaven: olfactory aspirations and discourses of desire. Social Semiotics, 27(3), pp. 310-322.

19.International Tourism Highlights. (2019). UNWTO.

https://www.e-unwto.org/doi/pdf/10.18111/9789284421152

20.Perfume Factory Gallimard. Grass. https://incomartour.com.ua/countries/1/1430

21.International guidelines for tourism statistics. (2008). https://unstats.un.org/unsd/publication/Seriesm/SeriesM_83rev1r.pdf

22.Feklisova, K. The best perfumery schools in France. https://www.buro247.ru/beauty/fragrance/iwant-to-be-a-perfumer.html

23.7 most interesting perfume museums in the world. https://www.malva-parfume.ua/blog/7samyh-interesnyh-parfyumernye-muzeev-mira/

24.Museum of Perfumery. http://provence-ukraine.com/news/muzei-parfjumerii-\%7C-provenceukraine-com.html

25.Musée du Parfum Fragonard. https://musee-parfum-paris.fragonard.com/en/

26. International Perfume Museum in Grasse.

https://ru.france.fr/ru/cote-d-azur/article/mezhdunarodny-muzey-parfumerii-v-grasse

27.Farina House - the most aromatic museum in Cologne.

https://www.dw.com/ru/\%D1\%84\%D0\%B0\%D1\%80\%D0\%B8\%D0\%BD\%D0\%B0-

\%D1\%85\%D0\%B0\%D1\%83\%D1\%81-\%D1\%81\%D0\%B0\%D0\%BC\%D1\%8B\%D0\%B9-

\%D0\%B0\%D1\%80\%D0\%BE\%D0\%BC\%D0\%B0\%D1\%82\%D0\%BD\%D1\%8B\%D0\%B9-

\%D0\%BC\%D1\%83\%D0\%B7\%D0\%B5\%D0\%B9-

\%D0\%BA\%D1\%91\%D0\%BB\%D1\%8C\%D0\%BD\%D0\%B0/a-2716014

28.Lukyanova, N. Museo Gal Perfumeria. https://elit-galand.ru/museumspain

29.Museum of Perfume. https://museodelprofumo.it/

30.Cairo Perfume Museum. http://www.openarium.ru/poi/31948521/ 